\title{
THE PROBLEM OF THE DEMAND FOR CROP INSURANCE: THE CASE OF SERBIA
}

\begin{tabular}{|c|c|}
\hline \multicolumn{2}{|c|}{$\begin{array}{l}\text { Vladimir Njegomir }{ }^{1} \text {, Jelena Demko Rihter }{ }^{2} \\
\text { *Corresponding author E-mail: jciric@uns.ac.rs }\end{array}$} \\
\hline ART I C LE IN F O & \multirow{9}{*}{$\begin{array}{l}\text { A B S T R A C T } \\
\text { Worldwide researches of the crop insurance suggest two } \\
\text { key problems: the lack of the insurer's interest for defining } \\
\text { supply and on the other side, insufficient interest of farm- } \\
\text { ers - potential insureds. The role of the state is necessary } \\
\text { in promoting insurance in agriculture, as well as in financ- } \\
\text { ing researches that are not exclusively commercial. Hav- } \\
\text { ing in mind numerous risks and forms of managing them, } \\
\text { starting from the fact that risk management is the basis of } \\
\text { economic survival of agricultural production, and the lack } \\
\text { of previous research in this area, our research is aimed at } \\
\text { identifying key incentive and restrictive factors that deter- } \\
\text { mine the demand of individual farmers for crop insurance } \\
\text { in Serbia. Different conclusions are made on the base of } 12 \\
\text { tested hypotheses related to the problem of promoting the } \\
\text { demand for crop insurance. Measures of dependence that } \\
\text { were used in this paper are Spearman's rank correlation } \\
\text { coefficient and Pearson's contingency coefficient. }\end{array}$} \\
\hline Original Article & \\
\hline Received: 21 May 2018 & \\
\hline Accepted: 19 June 2018 & \\
\hline doi:10.5937/ekoPolj1803995N & \\
\hline UDC 368.5(497.11) & \\
\hline Keywords: & \\
\hline $\begin{array}{l}\text { agriculture, crop insurance, } \\
\text { factors of demand, risk } \\
\text { management }\end{array}$ & \\
\hline JEL: $G 22, Q 1$ & \\
\hline
\end{tabular}

(C) 2018 EA. All rights reserved.

\section{Introduction}

Agricultural production has enormous social and economic importance worldwide. It is threatened by numerous risks, including natural disasters, variable weather conditions, uncertainty of yield and price. Research of the role of insurance in the financing damages caused by natural disasters and the improvement of agricultural production are generally rare. Worldwide researches suggest two key problems: the lack of the insurer's interest for setting supply and on the other side, insufficient interest of farmers - potential insureds. The state also has an important role in promoting insurance in agriculture. Insurers and state should inform and educate potential contractors of crop insurance in order to change their perception of insurance as an unnecessary cost.

Having in mind numerous risks and forms of managing them, starting from the fact that risk management is the basis of economic survival of agricultural production, and the lack of previous research in this area, our research is aimed at identifying key incentive and restrictive factors that determine the supply (the insurance sector) and demand (individual farmers) for insurance, as well as comparison to foreign experience and determination of possibilities and suggestions for improvements. The aim of the research is analyzing the role of crop insurance in financing the consequences of natural disasters and proposal of

1 Vladimir Njegomir, associate professor, Faculty of legal and business studies dr Lazar Vrkatić, Bulevar Oslobođenja 76 Novi Sad, 064/1393005, vnjegomir@useens.net, https://orcid.org/0000-0003-0148-6906

2 Jelena Demko Rihter, assistant professor, Faculty of technical sciences, Trg Dositeja Obradovića 6, Novi Sad, 021/4852173, jciric@uns.ac.rs, https://orcid.org/0000-0001-7762-3095 
solutions for improvement on the macro and micro level in order to provide sustainable development of agricultural production. Through the research we analyzed the factors that determine demand for crop insurance in Serbia. Some of those factors are the size of the damage at the level of individual farmer's household, attitudes of farmers in terms of risk management, the role of insurance and trust in the institution of insurance, as well as factors that determine the supply and capabilities and interest of the private sector for insurance.

The reminder of this article is organized as follows. After the Introduction, the second section presents the importance of promoting the demand for crop insurance as an instrument of risk management in agriculture. The data, methodology and empirical results are presented in the third section that is followed by the conclusion.

\section{The importance of the demand for crop insurance}

In the literature there are different classifications of the available treatment of risks of agricultural production. According to European Commission EC (2001) all forms of risk treatment can be classified into: 1) measures applied at farms (for example, selection of products with low risk exposure, short production cycles, diversification of product programs and vertical integration) and 2) measures of risk sharing (for example, agreements on agricultural production, contracts for the sale of agricultural products, futures, joint funds and insurance). Hirsch and Nell (2008) classify: 1) ex ante approaches, which involve the farmers' use of risk management activities before the realization of the damage (for example, diversification of crops, bio-security measures such as fencing cattle or implementation of hygienic conditions in the stables, as well as insurance ) and 2) ex post approaches which include measures after realization of the damage (for example, forced slaughter, herd rebuilding, sale of assets, the use of the loans, measures of state intervention in the event of catastrophic damage and the use of social programs funds). We consider that the classification of the different risk treatment in the agriculture according to the type of risk is the most important and regarding that are distinguished (Pejanović, Njegomir, 2011): 1) the general applicable management measures for all risks (for example, diversification, vertical integration, agreements on agricultural production, the creation of individual savings accounts, cooperatives and association of farmers), 2) the price risk management measures (for example, contracts sales of agricultural products, futures, options, swaps, forwards) and 3) production risk management measures (for example, preventive measures and insurance).

In managing agriculture production risk, key roles have prevention, the state and insurance. Risk prevention aims to prevent the realization or to reduce the probability of adverse events. The state intervention is justified only in cases when the risk management measures based on market principles are not applicable or not available. Insurance is the key mechanism of risk management in agriculture, especially in developed countries. Agricultural insurance is a special type of insurance and it is part of property insurance. Insurance companies in the world and in our country, recognizing the specific nature of agriculture insurance, set up special departments to deal with this type of insurance or the acquisition of this type of insurance is left to specialized agencies (Njegomir et al., 2017). 
Modern insurance as a form of risk management has been emerged with the development of private property and the development of mathematics and statistics, although the risk pooling as a basic characteristic of insurance existed in the first human community too, when people were joining together in groups or tribal in order to share risk with each other (Rejda, 2005). Individual farmers pay insurance premiums in order to provide protection from damages caused by hail, fire, theft of property of the farmer's household, livestock death or diseases, as well as death or illness of insured farmer. In Serbia in 2012 total agricultural insurance premium per farm was relatively small and amounted only about EUR 30, although there is possibility of $40 \%$ state subsidies for insurance premiums. Large number of farmers are still not contracting insurance of agriculture (Skakavac et al., 2017). According to the Čolović and Mrvić Petrović (2014) the main problem of crop insurance is not only existing the risk, but the way of providing protection through the crop insurance, too. They have analysed crop insurane in the USA, in some EU contries and Serbia too and highlighted three possibilities: insurance companies under the state control, public-private partnerships and private insurance companies that have business on a commercial basis.

The key role of insurance in the agricultural production and society in general is indirect economic protection of life and property from the adverse effects of natural forces and accidents. Insurance promotes agricultural production by making the entrepreneurial activities of farmers more stable and more certain. Insurance reduces the uncertainty of farmers and the need to create individual savings accounts or funds, given that the need for cash reserves is reduced (Raulston et al., 2010). It enables farmers to invest profitably their financial accumulation that further supports the development of agriculture. Insurance provides indirect economic protection in terms of the destructive effects of natural forces and activities of humans, but insurance is also a form of collateral that allows farmers easier access to the capital at lower costs. Njegomir et al. (2017) have also researched relation between climate changes and insurance of agriculture. After the extreme price rise of agricultural products and food in 2007 and 2008 it has been highlighted the importance of security of food supply whereby the Inter-American Institute for Cooperation in Agriculture pointed out that food safety is the most important issue today.

World Bank has a similar attitude which indicates that insurance companies do not commit enough attention to the crop insurance, which is one of the ten key factors in solving the problem of food supply crisis, represents a serious barrier to productivity, investments and efficiency of marketing systems in agriculture (World Bank, 2008). Additionally, crop insurance has become more important regarding the exclusion of state subsidies for the insurance premiums from the Free Trade Agreement of 1994 (World Trade Organization) with the argument that the insurance provides financial compensation for the climate and natural disasters (Baez, Wong, 2007).

Crop insurance has a different importance worldwide. Similar to the trends in the economy and society as well as the global trends in the insurance market, crop insurance is the most developed in developed countries. These trends are contrary to the relative importance of agriculture in these countries. However, in recent years there is a trend of increasing importance of crop insurance thanks to (Kaira, Xing, 2013): 
- large national insurance programs and/or increase of state support in the form of subsidies for insurance premiums;

- positioning of agriculture as a priority sector in a numerous emerging markets;

- the opening of the local agricultural sector to the global and private insurers, which resulted in offering more innovative insurance products and the transfer of global expertise and practices;

- innovations in crop insurance products, such as the index-based products and products with distant reading of factors needed for the analyses and even resolution of claims;

- increased focus of global reinsurers and supranational organizations to the development of crop insurance;

- $\quad$ public-private partnerships; These partnerships involve cooperation between governments and private insurers and reinsurers, and have emerged considerably in recent years. They contribute to the successful implementation of numerous programs of crop insurance in different regions of developing countries.

In some countries, such as India and Brazil, the state has a very important role in the field of crop insurance. In Argentina as well as in South Africa there is no government intervention and subsidies (Baez, Wong, 2007). Considering the countries of Eastern Europe, it can be noticed that state influence regarding crop insurance is present, but not enough.

In most countries, private crop insurance is not sustainable without state subsidies (Skees et al., 1999), although their amount is constantly increasing. In the period to 2007, subsidies for crop insurance premiums on the global level reached almost $\$ 12$ billion (Mahul, Stutley, 2010), while in 2011 only in the United States reached \$ 7.4 billion, or $62 \%$ of total crop insurance (GAO, 2012). Žarković et al. (2014) have also emphasized direct relationship between the involvment of the state and degree of crop insurance development. Having in mind global importance of food production, crop insurance is widely subsidized by governments of both deveoped and emerging countries.

Table 1. Comparative review of crop insurance state subsidies among the former Yugoslav countries

\begin{tabular}{|l|l|l|}
\hline Country & $\begin{array}{l}\text { State subsidies as a \% } \\
\text { of insurance premium }\end{array}$ & By-law regulation the amount of state subsidy \\
\hline Montenegro & $50 \%$ & $\begin{array}{l}\text { Agricultural budget } \\
\text { Ministry of agriculture and rural development of } \\
\text { Montenegro }\end{array}$ \\
\hline $\begin{array}{l}\text { Federation of } \\
\text { Bosnia and } \\
\text { Herzegovina }\end{array}$ & $\begin{array}{l}50 \%, \max . \text { to } 30000 \mathrm{KM} \\
(€ 15.339)\end{array}$ & $\begin{array}{l}\text { Rules on conditions and way of realization of financial } \\
\text { support to agriculture }\end{array}$ \\
\hline
\end{tabular}




\begin{tabular}{|c|c|c|}
\hline Country & $\begin{array}{l}\text { State subsidies as a \% } \\
\text { of insurance premium }\end{array}$ & By-law regulation the amount of state subsidy \\
\hline Croatia & $\begin{array}{l}25 \%, \text { max. to } \\
500000 \mathrm{HRK} \\
(€ 66.483) \\
\text { additionally to } 25 \%\end{array}$ & $\begin{array}{l}\text { Rules on realisation right for support in case of } \\
\text { possible damages in agriculture } \\
\text { Rules of particular districts }\end{array}$ \\
\hline FYR Macedonia & $\begin{array}{l}60 \%, \text { max. to } \\
200000 \mathrm{MKD} \\
(€ 3.247)\end{array}$ & Agriculture and rural development law \\
\hline Republic of Srpska & $\begin{array}{l}50 \%, \text { max. to } 25000 \mathrm{KM} \\
(€ 12.782)\end{array}$ & $\begin{array}{l}\text { Rules on conditions and way of realization of financial } \\
\text { support for development of agriculture and villages }\end{array}$ \\
\hline Slovenia & $\begin{array}{l}40 \% \text { for crops } \\
30 \% \text { for livestock } \\
\text { with municipal subsidies } \\
\text { upto } 50 \%\end{array}$ & Regulation on cofinancing crop insurance premiums \\
\hline Serbia & $\begin{array}{l}40 \% \text {, with possibility } \\
\text { of additional municipal } \\
\text { subsidies }\end{array}$ & $\begin{array}{l}\text { Regulation on conditions and way of cofinancing } \\
\text { premiums for insurance of crops, livestock, young } \\
\text { vineyards and orchards }\end{array}$ \\
\hline
\end{tabular}

Source: author's compilation from various sources stated in the table

Data in Table 1 suggest that there are state subsidies for crop insurance and livestock insurance in all former Yugoslav countries and they vary in percent of total payed insurance premium. State subsidies for crop insurance premiums are usually set by Ministry of agriculture and implemented by Agriculture and rural development law or some other by-law regulations and rules related to agriculture, rural development and co-financing of crop insurance premiums. In Serbia and Croatia there is possibility for additional subsidies financed by municipalities or districts. Regardless the state subsidies and increasing negative impact of climate changes on the agriculture, demand for the crop insurance is still underdeveloped (Njegomir et al., 2016).

\section{Data and methodology}

Our focus in this paper is analyzing factors that booster demand for crop insurance as a mechanism of risk management in the agriculture. On the basis of available literature and empirical evidence (answers of survey participants) we set 12 hypotheses in order to test factors that have prevalent impact on promoting crop insurance in Serbia. We used statistical analysis for data processing, analyzing and presenting.

There were 170 survey participants, engaged in agriculture as a core business and source of household's income or agriculture is their side business, combined with some other kind of activities and income sources. Descriptive statistics measures were used for sample description. Measures of dependence that were used in this paper are Spearman's rank correlation coefficient and Pearson's contingency coefficient. Spearman's rank correlation coefficient $(\rho)$ is used to identify and test the strength of a relationship between two sets of data. Spearman's $\rho$ is the non-parametric test which means it does 
not rely on data belonging to any particular distribution. Spearman's $\rho$ is equivalent of the Pearson product-moment correlation coefficient. Their results and the way of calculating are closely similar, but the Spearman's $\rho$ first ranks the data. Pearson's contingency coefficient is a measure of the relative strength of any association between two variables. The coefficient always has value less than 1 and varies according to the number of rows and columns.

Calculating of the Pearson's contingency coefficient:

$$
C=\sqrt{\frac{X^{2}}{n+X^{2}}}
$$

\section{Results and discussions}

In this paper we have set and tested 12 hypotheses.

\section{H1: Higher level of formal education has impact on increasing interest for contracting crop insurance}

Through the analysis of the education of respondents, it can be seen that $65 \%$ of them completed high school, $15 \%$ of them completed primary school and $20 \%$ of respondents were highly educated, which indicated the increasing level of education of people engaged in agriculture business. Testing by Spearman's rank correlation coefficient $(\rho)$ it was not identified linear relationship between two variables: interest for contracting crop insurance and level of formal education $\left(\rho_{s}=0,058, p=0,453\right)$. The relationship between these variables is nonlinear.

Hypothesis is partly confirmed.

Contingency coefficient showed statistically significant relationship between these two variables $\left(C=0,194, \chi^{2}=6,622, p=0,04\right)$.

Table 2. Crosstabulation of interest for contracting crop insurance and level of formal education

\begin{tabular}{|l|l|l|l|l|}
\hline \multicolumn{2}{|c|}{} & \multicolumn{2}{|c|}{$\begin{array}{c}\text { Interest for contracting crop } \\
\text { insurance }\end{array}$} & \multirow{2}{*}{ Total } \\
\cline { 3 - 5 } \multicolumn{2}{|c|}{} & \multicolumn{2}{|c|}{ no } & \multicolumn{2}{c|}{ yes } & \\
\hline \multirow{3}{*}{ Formal education } & Primary school & 15 & 10 & 25 \\
\cline { 2 - 5 } & High school & 86 & 28 & 114 \\
\cline { 2 - 5 } & Faculty & 16 & 14 & 30 \\
\hline Total & 117 & 52 & 169 \\
\hline
\end{tabular}

Source: author's calculations

Data in Table 2 show that although high school respondents were dominant in the sample, only $25 \%$ of them were interested for contracting crop insurance, in comparison to $40 \%$ of primary school respondents and $47 \%$ of respondents with faculty degree. 
H2: Demand for crop insurance depends on perception of contracting crop insurance.

Contingency coefficient showed statistically significant relationship between demand for crop insurance and perception of contracting crop insurance $(C=0,393, \chi 2=27,437$, $\mathrm{p}=0,000)$.

Hypothesis is confirmed.

Table 3. Relationship between two variables determined by contingency coefficient (C)

\begin{tabular}{|l|r|}
\hline & \multicolumn{1}{|r|}{ Value } \\
\hline$\chi^{2}$ & 27.437 \\
\hline $\mathrm{C}$ & .393 \\
\hline $\mathrm{df}$ & 3 \\
\hline $\mathrm{p}$ & .000 \\
\hline $\mathrm{N}$ & 150 \\
\hline & \\
\hline
\end{tabular}

Source: author's calculations

Table 4. Crosstabulation of variables demand for crop insurance and motives of contracting crop insurance, with review of answers

\begin{tabular}{|c|c|c|c|c|}
\hline & \multicolumn{2}{|c|}{$\begin{array}{c}\text { Contracting } \\
\text { crop } \\
\text { insurance }\end{array}$} & \multirow[t]{2}{*}{ Total } \\
\hline & & no & yes & \\
\hline \multirow{4}{*}{$\begin{array}{l}\text { Motives of } \\
\text { contracting } \\
\text { crop insurance }\end{array}$} & Insurance as a precondition for getting a loan & 5 & 0 & 5 \\
\hline & $\begin{array}{l}\text { Insurance is necessary for the protection of } \\
\text { damages caused by natural disasters }\end{array}$ & 43 & 44 & 87 \\
\hline & Insurance is recommended by friend or neighbour & 1 & 2 & 3 \\
\hline & I don’t know & 49 & 6 & 55 \\
\hline \multicolumn{2}{|l|}{ Total } & 98 & 52 & 150 \\
\hline
\end{tabular}

Source: author's calculations

Even $85 \%$ out of total number of respondents who contracted crop insurance consider that insurance is necessary tool of protection in case of damages caused by natural disasters. Other motives (answers) given to the respondents are mainly not important for their decision to insure their agricultural business, while the majority of respondents do not have motive and reason to insure their agricultural production.

This result indicates that there are necessary continuous and long-term efforts in order to increase level of awareness of current and potential insured in the branch of agriculture and to give them additional information about the advantages of crop insurance.

\section{H3: Demand for crop insurance depends on purpose of doing agricultural business}

Pearson's Chi-square test suggest there is no statistically significant relationship between the demand for crop insurance and purpose of doing agricultural business, except in the case of doing agriculture as a core business, where is suggested marginal statistical significance. $(\mathrm{p}=0,077)$. 
Table 5. Relationship between variables determined by Phi coefficient and Chi-square $\left(\chi^{2}\right)$

\begin{tabular}{|c|c|c|}
\hline \multicolumn{2}{|l|}{ Purpose } & \multirow{2}{*}{$\begin{array}{r}\text { Contracting crop insurance } \\
3.122\end{array}$} \\
\hline \multirow{4}{*}{$\begin{array}{l}\text { Agriculture as a core business and main source } \\
\text { of household's income }\end{array}$} & $\chi^{2}$ & \\
\hline & $\Phi$ & .136 \\
\hline & $\mathrm{df}$ & 1 \\
\hline & $\mathrm{p}$ & .077 \\
\hline \multirow{4}{*}{$\begin{array}{l}\text { Agricultural production as a source of satisfying } \\
\text { basic household's needs }\end{array}$} & $\chi^{2}$ & .382 \\
\hline & $\Phi$ & .047 \\
\hline & $\mathrm{df}$ & 1 \\
\hline & $\mathrm{p}$ & .536 \\
\hline \multirow{4}{*}{$\begin{array}{l}\text { Agriculture as additional source of household's } \\
\text { income }\end{array}$} & $\chi^{2}$ & 1.306 \\
\hline & $\Phi$ & -.042 \\
\hline & $\mathrm{df}$ & 1 \\
\hline & $\mathrm{p}$ & .253 \\
\hline & & \\
\hline
\end{tabular}

Source: author's calculations

Table 6. Crosstabulation of variables demand for crop insurance and purpose of doing agricultural business, with review of answers

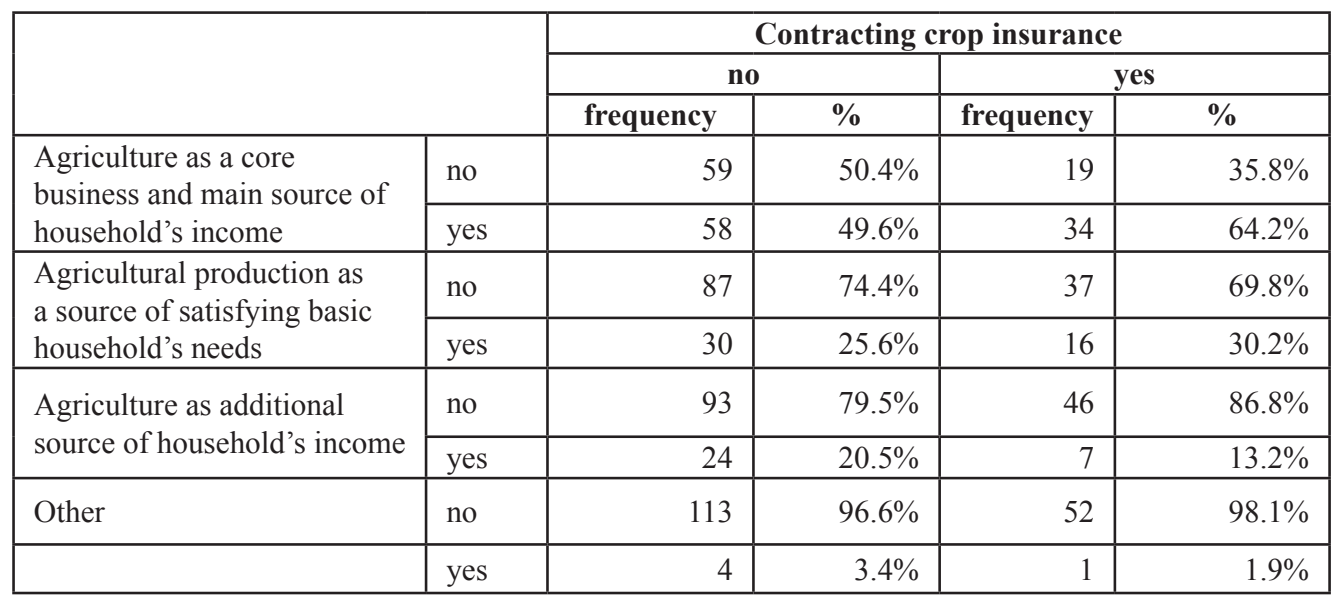

Source: author's calculations

By reviewing frequency of answers of respondents it can be seen that respondents whom agriculture is a core business and the main source of household's income, are the main group of respondents $(64 \%)$ interested in contracting insurance of their agricultural production. Only $30 \%$ of respondents who organize own agricultural production in order to satisfy the basic needs of their households and $13 \%$ of respondents whom income from the agriculture is additional income, are interested in contracting crop insurance.

Hypothesis is rejected. 
H4: Demand for crop insurance depends on annual household's profit of agricultural production

Spearman's rank correlation coefficient $(\rho)$ suggest statistically significant linear relationship between the demand for crop insurance and annual household's profit of agricultural production $(\rho S=0,341, \mathrm{p}=0,000)$.

Hypothesis is confirmed.

Contingency coefficient shows statistically significant relationship between demand for crop insurance and annual household's profit of agricultural production $(C=0,386$, $\chi 2=29,609, \mathrm{p}=0,000)$.

Table 7. Crosstabulation of variables demand for crop insurance and annual household's profit of agricultural production, with review of answers

\begin{tabular}{|c|c|c|c|c|}
\hline & \multicolumn{2}{|c|}{ Contracting crop insurance } & \multirow{2}{*}{ Total } \\
\hline & & no & yes & \\
\hline \multirow{5}{*}{$\begin{array}{l}\text { Annual profit of } \\
\text { agricultural production }\end{array}$} & Below EUR 2.000 & 31 & 3 & 34 \\
\hline & $\begin{array}{l}\text { Between EUR } 2.000 \text { and } \\
4.000\end{array}$ & 18 & 6 & 24 \\
\hline & $\begin{array}{l}\text { Between EUR } 4.000 \text { and } \\
6.000\end{array}$ & 15 & 3 & 18 \\
\hline & $\begin{array}{l}\text { Between EUR } 6.000 \text { and } \\
10.000\end{array}$ & 14 & 4 & 18 \\
\hline & Above EUR 10.000 & 39 & 37 & 76 \\
\hline \multicolumn{2}{|l|}{ Total } & 117 & 53 & 170 \\
\hline
\end{tabular}

Source: author's calculations

Data in Table 7 suggest that out of total number of respondents that have declared that they insure their agricultural production, even $70 \%$ of respondents (households) have earned more than EUR 10.000 by doing agricultural business. This result has been expected, having in mind that respondents who organize agricultural production on the larger arable land, have larger investment in agriculture, but higher income, expenditures and profit, too. Due to higher exposure to risk and larger potential losses in the agriculture, they are more interested in the insurance. Other groups of respondents who have annual profit below EUR 10.000 are less interested in contracting insurance of their agricultural production.

H5: Demand for crop insurance depends on key causers of losses in agriculture Pearson's Chi-square test suggests there is no statistically significant relationship between the demand for crop insurance and key causers of losses in agriculture.

Hypothesis is rejected. 
Table 8. Relationship between variables determined by Phi coefficient and Chi-square $\left(\chi^{2}\right)$

\begin{tabular}{|l|c|c|}
\hline \multirow{4}{*}{$\begin{array}{l}\text { Natural disasters (drought, flood, } \\
\text { hail, frost, etc) }\end{array}$} & $\chi^{2}$ & Contracting crop insurance \\
\cline { 2 - 3 } & $\Phi$ & .918 \\
\cline { 2 - 3 } & $\mathrm{df}$ & .073 \\
\cline { 2 - 3 } & $\mathrm{p}$ & 1 \\
\hline \multirow{3}{*}{$\begin{array}{l}\text { Increase of production costs } \\
\text { (increase of purchase price of seed, } \\
\text { fuel, fertilizer, etc.) }\end{array}$} & $\chi^{2}$ & .338 \\
\cline { 2 - 3 } & $\Phi$ & 2.342 \\
\cline { 2 - 3 } & $\mathrm{df}$ & .117 \\
\hline \multirow{4}{*}{$\begin{array}{l}\text { Decrease of selling price of } \\
\text { agricultural products }\end{array}$} & $\mathrm{p}$ & 1 \\
\cline { 2 - 3 } & $\chi^{2}$ & .126 \\
\cline { 2 - 3 } & $\Phi$ & .106 \\
\hline \multirow{3}{*}{\begin{tabular}{l} 
Infectious diseases, pests \\
\cline { 2 - 3 }
\end{tabular}} & $\mathrm{df}$ & -.025 \\
\cline { 2 - 3 } & $\mathrm{p}$ & 1 \\
\cline { 2 - 3 } & $\chi^{2}$ & .745 \\
\cline { 2 - 3 } & $\Phi$ & .676 \\
\hline & $\mathrm{df}$ & .063 \\
\hline
\end{tabular}

Source: author's calculations

Note: a. More than $20 \%$ of cells have expected frequency of 5, result might be unstable

Table 9. Crosstabulation of variables demand for crop insurance and key causers of losses in agriculture, with review of answer

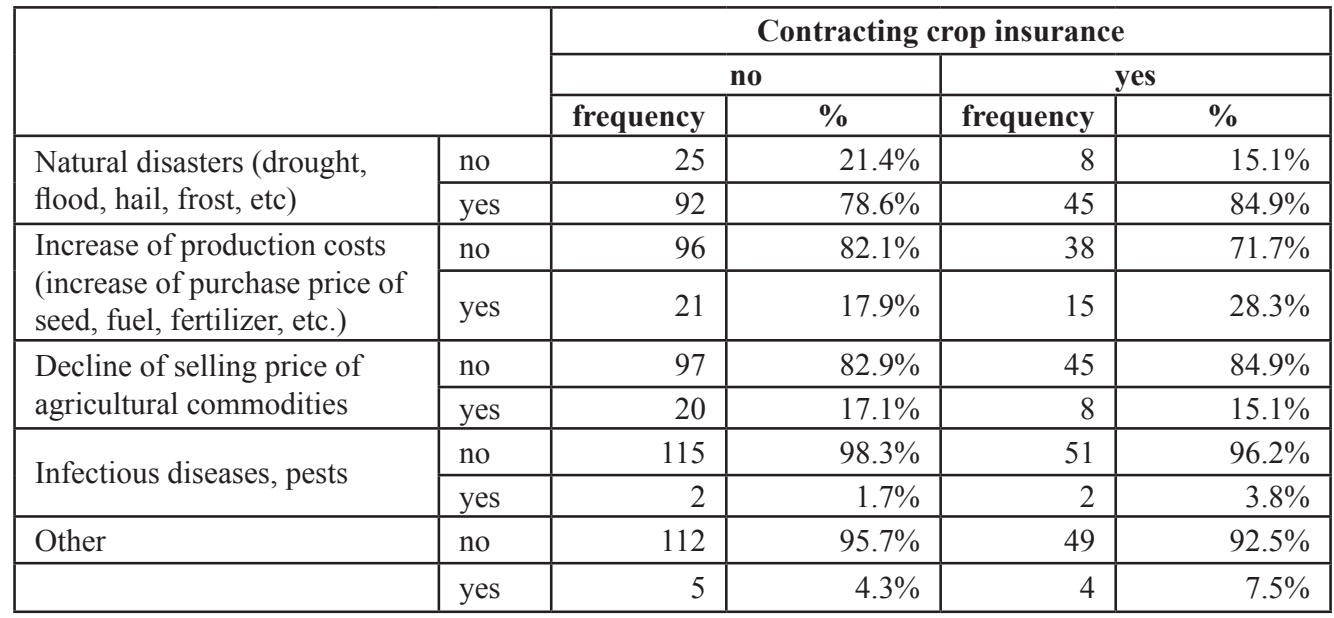

Source: author's calculations 
Data in table indicate that the majority of respondents $(85 \%)$ contracted insurance of their agricultural production in order to prevent themselves from the losses caused by natural disasters (drought, flood, hail, frost, etc.) that are even more frequent and intensive in the last decade. Other suggested causers of losses in the agricultural production (increase of production costs, decline of selling price of agricultural commodities, infectious diseases and pests) mainly do not affect decision of respondents regarding contracting crop insurance.

\section{H6: Demand for crop insurance depends on using state subsidy for compensation}

Phi coefficient suggests there is statistically significant relationship between the demand for crop insurance and using state subsidy for compensation $(\Phi=0,324, \chi 2=17,676$, $\mathrm{p}=0,000)$.

Hypothesis is confirmed.

Table 10. Crosstabulation of variables demand for crop insurance and using state subsidy for compensation, with review of answers

\begin{tabular}{|l|l|r|r|r|}
\hline \multicolumn{2}{|c|}{} & \multicolumn{2}{|c|}{ Contracting crop insurance } & \multirow{2}{*}{ Total } \\
\cline { 3 - 4 } \multicolumn{2}{|c|}{} & no & yes & \\
\hline $\begin{array}{l}\text { Using state subsidy for } \\
\text { compensation }\end{array}$ & no & 109 & 38 & 147 \\
\cline { 2 - 5 } & yes & 6 & 15 & 21 \\
\hline Total & 115 & 53 & 168 \\
\hline
\end{tabular}

Source: author's calculations

Data in table indicate that $87,5 \%$ of total number of respondents do not use state subsidies for compensation. In the group of respondents $(12,5 \%)$ that use state subsidies for compensation, majority of them $(71 \%)$ decide for crop insurance. Respondents who are users of state subsidies for compensation are more interested in crop insurance.

\section{H7: Demand for crop insurance depends on application of preventive measures in agricultural production (as an alternative of insurance)}

Pearson's Chi-square test suggests there is statistically significant relationship between the demand for crop insurance and application of preventive measures in agricultural production (as alternative of insurance) only if protective measures are not applied. There is no statistically significant relationship between the demand for crop insurance and preventive measure such as advanced protection and selection of crops, but there is marginal statistical significance between the demand for crop insurance and protective measure such as crops rotation $(\mathrm{p}=0.077)$. Respondents who have declared that their households do not insure their agricultural production, mainly do not apply risk prevention systems $\left(\Phi=-.318, \chi^{2}=17,175, \mathrm{p}=0,000\right)$.

Hypothesis is rejected. 
Table11. Relationship between variables determined by Phi coefficient and Chi-square $\left(\chi^{2}\right)$

\begin{tabular}{|l|l|r|}
\hline \multicolumn{2}{|c|}{} & Contracting crop insurance \\
\hline \multirow{4}{*}{$\begin{array}{l}\text { Advanced protection (irrigation, hail } \\
\text { protection, etc.) }\end{array}$} & $\chi^{2}$ & .606 \\
\cline { 2 - 3 } & $\mathrm{df}$ & 1 \\
\cline { 2 - 3 } & $\Phi$ & -.060 \\
\cline { 2 - 3 } & $\mathrm{p}$ & .436 \\
\hline \multirow{4}{*}{ Crops' choice } & $\chi^{2}$ & .001 \\
\cline { 2 - 3 } & $\mathrm{df}$ & 1 \\
\cline { 2 - 3 } & $\Phi$ & .003 \\
\cline { 2 - 3 } & $\mathrm{p}$ & .971 \\
\hline \multirow{4}{*}{$\begin{array}{l}\text { Crops' rotation } \\
\text { I do not apply measures of risk's }\end{array}$ management } & $\chi^{2}$ & 3.122 \\
\cline { 2 - 3 } & $\mathrm{df}$ & 1 \\
\cline { 2 - 3 } & $\Phi$ & -.136 \\
\cline { 2 - 3 } & $\mathrm{p}$ & .077 \\
\cline { 2 - 3 } & $\chi^{2}$ & 17.175 \\
\cline { 2 - 3 } & $\mathrm{df}$ & 1 \\
\cline { 2 - 3 } & $\Phi$ & .318 \\
\cline { 2 - 3 } & $\mathrm{p}$ & $.000^{*}$ \\
\hline \hline
\end{tabular}

Source: author's calculations

Note:*Relationship is significant at the level of statistical confidence $<0,01$

Table 12. Crosstabulation of variables demand for crop insurance and application of protective measures in agricultural production with review of answers

\begin{tabular}{|l|l|c|c|c|c|c|c|}
\hline \multirow{2}{*}{} & \multicolumn{6}{|c|}{ Contracting crop insurance } \\
\cline { 3 - 8 } \multicolumn{2}{|c|}{} & \multicolumn{2}{|c|}{ no } & & \multicolumn{2}{c|}{ yes } & \\
\cline { 2 - 8 } & frequency & $\%$ & $\%$ & frequency & $\%$ & $\%$ \\
\hline $\begin{array}{l}\text { Advanced protection } \\
\text { (irrigation, hail } \\
\text { protection, etc.) }\end{array}$ & no & 101 & $86.30 \%$ & $67.79 \%$ & 48 & $90.60 \%$ & $32.21 \%$ \\
\cline { 2 - 8 } & yes & 16 & $13.70 \%$ & $76.19 \%$ & 5 & $9.40 \%$ & $23.81 \%$ \\
\hline \multirow{2}{*}{ Crops' selection } & no & 82 & $70.10 \%$ & $68.91 \%$ & 37 & $69.80 \%$ & $31.09 \%$ \\
\cline { 2 - 8 } & yes & 35 & $29.90 \%$ & $68.63 \%$ & 16 & $30.20 \%$ & $31.37 \%$ \\
\hline \multirow{2}{*}{ Crops' rotation } & no & 58 & $49.60 \%$ & $63.04 \%$ & 34 & $64.20 \%$ & $36.96 \%$ \\
\cline { 2 - 8 } & yes & 59 & $50.40 \%$ & $75.64 \%$ & 19 & $35.80 \%$ & $24.36 \%$ \\
\hline \multirow{2}{*}{$\begin{array}{l}\text { I do not apply } \\
\text { measures of risk's } \\
\text { management }\end{array}$} & no & 86 & $73.50 \%$ & $61.87 \%$ & 53 & $100.00 \%$ & $38.13 \%$ \\
\cline { 2 - 8 } & yes & 31 & $26.50 \%$ & $100.00 \%$ & 0 & $0.00 \%$ & $0.00 \%$ \\
\hline
\end{tabular}

Source: author's calculations

Data in table show that majority of respondents do not apply measures of risk management in agriculture. It has to be emphasized that respondents do not perceive insurance as a measure of risk management. Also, in questionnaire was option to choose more than one measure of risk management and this fact could cause such statistical result. Majority of respondents that apply other preventive measures in agricultural production, do not contract crop insurance. 
H8: Demand for crop insurance depends on estimation of percentage decrease in total yield caused by natural disaster

Testing by Spearman's rank correlation coefficient $(\rho)$ it is not identified statistically significant linear relationship between two variables: demand for crop insurance and estimation of percentage decrease in total yield caused by natural disaster $\left(\rho_{\mathrm{S}}=-0,079\right.$, $\mathrm{p}=0,312)$.

Contingency coefficient shows there is no statistically significant relationship between demand for crop insurance and estimation of percentage decrease in total yield caused by natural disaster $\left(C=0,125, \chi^{2}=2,670, p=0,125\right)$.

Hypothesis is rejected.

Table 13. Crosstabulation of variables demand for crop insurance and percentage decrease in total yield caused by natural disaster with review of answers

\begin{tabular}{|c|c|c|c|c|}
\hline & \multicolumn{2}{|c|}{ Contracting crop insurance } & \multirow{2}{*}{ Total } \\
\hline & & no & yes & \\
\hline \multirow{5}{*}{$\begin{array}{l}\text { Percentage decrease in total } \\
\text { yield caused by natural } \\
\text { disaster }\end{array}$} & $0 \%$ to $20 \%$ & 17 & 11 & 28 \\
\hline & $20 \%$ to $40 \%$ & 62 & 28 & 90 \\
\hline & $40 \%$ to $60 \%$ & 29 & 9 & 38 \\
\hline & $60 \%$ to $80 \%$ & 6 & 4 & 10 \\
\hline & $80 \%$ to $100 \%$ & 1 & 0 & 1 \\
\hline \multicolumn{2}{|l|}{ Total } & 115 & 52 & 167 \\
\hline
\end{tabular}

Source: author's calculations

According to data in table $69 \%$ of total number of respondents do not contract crop insurance, regardless of negative impact of natural disaster on yields in agriculture. Among the rest of respondents who contract crop insurance, there is significant participation of group of respondents who declared that their yields in agriculture have been decreased for about 20 to $40 \%$ caused by natural disaster.

\section{H9: Demand for crop insurance depends on size of agricultural land cultivated by respondent}

Spearman's rank correlation coefficient $(\rho)$ suggest statistically significant linear relationship between the demand for crop insurance and size of agricultural land cultivated by respondent $\left(\rho_{\mathrm{S}}=0,347, \mathrm{p}=0,000\right)$.

Contingency coefficient shows statistically significant relationship between demand for crop insurance and size of agricultural land cultivated by respondent $(C=0,386$, $\left.\chi^{2}=29,609, \mathrm{p}=0,000\right)$.

Hypothesis is confirmed. 
Table 14. Crosstabulation of variables demand for crop insurance and size of agricultural land cultivated by respondent with review of answers

\begin{tabular}{|c|c|c|c|c|}
\hline & \multicolumn{2}{|c|}{ Contracting crop insurance } & \multirow{2}{*}{ Total } \\
\hline & & no & yes & \\
\hline \multirow{6}{*}{$\begin{array}{l}\text { Size of agricultural land } \\
\text { cultivated by respondent }\end{array}$} & $0,5-1$ ha & 17 & 1 & 18 \\
\hline & $1-3$ ha & 17 & 2 & 19 \\
\hline & $3-5$ ha & 18 & 1 & 19 \\
\hline & $5-10$ ha & 11 & 2 & 13 \\
\hline & $10-20$ ha & 8 & 11 & 19 \\
\hline & above 20 ha & 45 & 36 & 81 \\
\hline \multicolumn{2}{|l|}{ Total } & 116 & 53 & 169 \\
\hline
\end{tabular}

Source: author's calculations

According to data in table, $69 \%$ of total number of respondents do not contract crop insurance and within the group of remaining $31 \%$ of respondents who pay insurance premium, the majority of them $(68 \%)$ cultivate more than 20 hectares of arable land. For this group of respondents is highly important to transfer risk and losses that might occur in agricultural production to the insurance companies through paying of insurance premium.

\section{H10: Demand for crop insurance depends on perception of insurance as a cost or an investment}

Phi coefficient suggests there is statistically significant relationship between the demand for crop insurance and perception of insurance as a cost or investment $(\Phi=-0,430$, $\left.\chi^{2}=28,605, \mathrm{p}=0,000\right)$.

Hypothesis is confirmed.

Table 15. Crosstabulation of variables demand for crop insurance and perception of insurance as a cost or an investment with review of answers

\begin{tabular}{|l|l|r|r|r|}
\hline \multicolumn{2}{|c|}{} & \multicolumn{2}{|c|}{ Contracting crop insurance } & \multirow{2}{*}{ Total } \\
\cline { 3 - 5 } \multicolumn{2}{|c|}{} & no & yes & \\
\hline $\begin{array}{l}\text { Perception of insurance } \\
\text { as a cost or investment }\end{array}$ & investment & 31 & 36 & 67 \\
\cline { 2 - 5 } & cost & 76 & 12 & 88 \\
\hline Total & 107 & 48 & 155 \\
\hline
\end{tabular}

Source: author's calculations

As it has been commented earlier, only $31 \%$ of total number of respondent's contract insurance of their agricultural production and look on insurance premium as an investment, not as a cost. Major of respondents (69\%) who are not interested in crop insurance, consider insurance premium as a cost (71\% of respondents in this group). This suggests necessity of education of farmers as potential insured through providing them additional information regarding insurance as a measure of managing risks, that are agricultural production is exposed to. 
H11: Demand for crop insurance depends on possibility of realization income out of agriculture

Phi coefficient suggests there is statistically significant relationship between the demand for crop insurance and possibility of realization income out of agriculture $(\Phi=-0,155$, $\chi 2=4,053, \mathrm{p}=0,044)$.

Hypothesis is confirmed.

Table 16. Crosstabulation of variables demand for crop insurance and possibility of realization income besides agriculture with review of answers

\begin{tabular}{|l|l|c|c|r|}
\hline \multicolumn{2}{|c|}{} & \multicolumn{2}{|c|}{ Contracting crop insurance } & \multirow{2}{*}{ Total } \\
\cline { 3 - 4 } \multicolumn{2}{|c|}{} & no & yes & 101 \\
\hline $\begin{array}{l}\text { possibility of realization } \\
\text { income besides agriculture }\end{array}$ & no & 64 & 37 & 68 \\
\cline { 2 - 5 } & yes & 53 & 15 & 169 \\
\hline Total & 117 & 52 & \\
\hline
\end{tabular}

Source: author's calculations

Respondents who realize income only within agriculture are more interested in crop insurance. In the group of $31 \%$ of total number of respondents who insure their agricultural production, $71 \%$ of them do not realize income out of agriculture. It has been expected, regarding that in case of risk and losses in agriculture, yield and income of this group of respondents would be threatened and next season agricultural production would be organized in the same or even smaller scale.

\section{H12: Demand for crop insurance depends on type of agricultural production}

Pearson's Chi-square test suggests there is statistically significant relationship between the demand for crop insurance and crop husbandry, but not the other types of agricultural production.

Hypothesis is partly confirmed.

Table 17. Relationship between variables determined by Phi coefficient and Chi-square $\left(\chi^{2}\right)$

\begin{tabular}{|l|c|c|}
\hline \multicolumn{2}{|c|}{} & Contracting crop insurance \\
\hline \multirow{4}{*}{ Crop husbandry } & $\chi^{2}$ & 5.900 \\
\cline { 2 - 3 } & $\Phi$ & .186 \\
\cline { 2 - 3 } & $\mathrm{df}$ & 1 \\
\cline { 2 - 3 } & $\mathrm{p}$ & $.015^{*}$ \\
\hline \multirow{4}{*}{ Fruit growing } & $\chi^{2}$ & .138 \\
\hline & $\Phi$ & -.028 \\
\hline & $\mathrm{df}$ & 1 \\
\cline { 2 - 3 } & $\mathrm{p}$ & .710 \\
\hline \multirow{4}{*}{ Wine growing } & $\chi^{2}$ & 2.334 \\
\cline { 2 - 3 } & $\Phi$ & -.117 \\
\cline { 2 - 3 } & $\mathrm{df}$ & 1 \\
\cline { 2 - 3 } & $\mathrm{p}$ & $.127^{\mathrm{a}}$ \\
\hline
\end{tabular}




\begin{tabular}{|c|c|c|}
\hline & & Contracting crop insurance \\
\hline \multirow{4}{*}{ Vegetable growing } & $\chi^{2}$ & .613 \\
\hline & $\Phi$ & -.060 \\
\hline & $\mathrm{df}$ & 1 \\
\hline & $\mathrm{p}$ & .434 \\
\hline \multirow{4}{*}{ Livestock husbandry } & $\chi^{2}$ & .510 \\
\hline & $\Phi$ & -.055 \\
\hline & $\mathrm{df}$ & 1 \\
\hline & $\mathrm{p}$ & .475 \\
\hline
\end{tabular}

Source: author's calculations

Note: a. More than $20 \%$ of cells have expected frequency below 5 and value of Chi-square $\left(\chi^{2}\right)$ is not reliable

* Relationship is significant at the level of statistical reliability below 0,01

Among the respondents who deal in crop husbandry, majority of them pay premium for crop insurance $\left(\Phi=0,186, \chi^{2}=5,900, \mathrm{p}=0,015\right)$.

Table 18. Crosstabulation of variables demand for crop insurance and type of agricultural production with review of answers

\begin{tabular}{|c|c|c|c|c|c|}
\hline & \multicolumn{4}{|c|}{ Contracting crop insurance } \\
\hline & & \multicolumn{2}{|c|}{ no } & \multicolumn{2}{|c|}{ yes } \\
\hline & & frequency & percent & frequency & percent \\
\hline \multirow{2}{*}{ Crop husbandry } & no & 27 & $23.1 \%$ & 4 & $7.5 \%$ \\
\hline & yes & 90 & $76.9 \%$ & 49 & $92.5 \%$ \\
\hline \multirow{2}{*}{ Fruit growing } & no & 99 & $84.6 \%$ & 46 & $86.8 \%$ \\
\hline & yes & 18 & $15.4 \%$ & 7 & $13.2 \%$ \\
\hline \multirow{2}{*}{ Wine growing } & no & 112 & $95.7 \%$ & 53 & $100.0 \%$ \\
\hline & yes & 5 & $4.3 \%$ & 0 & $.0 \%$ \\
\hline \multirow{2}{*}{ Vegetable growing } & no & 91 & $77.8 \%$ & 44 & $83.0 \%$ \\
\hline & yes & 26 & $22.2 \%$ & 9 & $17.0 \%$ \\
\hline \multirow{2}{*}{ Livestock husbandry } & no & 94 & $80.3 \%$ & 45 & $84.9 \%$ \\
\hline & yes & 23 & $19.7 \%$ & 8 & $15.1 \%$ \\
\hline \multirow[t]{2}{*}{$\begin{array}{l}\text { Other types of agricultural } \\
\text { production }\end{array}$} & no & 116 & $99.1 \%$ & 52 & $98.1 \%$ \\
\hline & yes & 1 & $.9 \%$ & 1 & $1.9 \%$ \\
\hline
\end{tabular}

Source: author's calculations

On the base of data in Table 18 it can be noticed that in the group of respondents $(31 \%)$ who contract crop insurance, $92 \%$ of them are engaged in crop husbandry. There is almost equal participation of groups of respondents who are engaged in vegetable growing $(17 \%)$, livestock husbandry $(15 \%)$ and wine growing and who are contracting insurance of their agricultural production. Crop husbandry is dominant type of agricultural production, comparing arable land used for crop husbandry on the one side and wine growing or vegetable growing on the other side. Regarding that, larger amount of investments, but larger potential losses in case of risk realization can be expected. This might be the main reason and explanation why farmers engaged in crop husbandry are more interested in crop insurance. 


\section{Conclusions}

Summarizing twelve tested hypotheses following can be concluded. Higher level of formal education of farmers does not necessarily mean that they will be more interested in crop insurance, although it was expected, but nonlinear relationship between these two variables was found in the sample and hypothesis is only partly confirmed. It has also been supposed that households and farmers who earned higher profit in agricultural business and cultivate more arable land are more interested and express increasing demand for contracting crop insurance and those hypotheses are confirmed. We have been aware that interest for contracting crop insurance depends a lot of farmers' perception of insurance premium as a cost of as an investment and this hypothesis is confirmed. It means that farmers who think that paying insurance premium is only cost mainly do not contract insurance of their agricultural production, unlike the farmers who perceive insurance premium as an investment. In this context the motive for deciding for insurance also has influence on demand for insurance. Farmers as current and potential insured should be aware and in detail informed about advantages of insurance, as a measure of risk management in order to decide more for insurance of their agricultural production. It is also important whether farmers realize some additional income out of agriculture or not. If agriculture is their core business and the main source of income of their households, in case of natural disaster and other risks in agriculture their investments can be more threatened with possibility of large losses. As it has been expected this group of farmers is more interested for insurance. The majority of farmers are engaged in crop husbandry and having in mind bigger arable land and greater investments in this type of agricultural production comparing to fruit, vegetable or wine growing, it was expected that this group of farmers would express greater interest for insurance. The majority of respondents do not use state subsidy for compensation of damages and logically they rather not decide for crop insurance and this hypothesis is also confirmed.

Although the majority of respondents that contract insurance of their agricultural production tend to prevent themselves from the losses caused by natural disasters (drought, flood, hail, frost, etc.), that are even more frequent and intensive in the last decade, there is no statistically significant relationship between the demand for insurance and key causers of losses in agriculture and the hypothesis is rejected. The majority of respondents estimate that their total yield has been decreased for approximately 20 to 40 percent caused by natural disaster, but they still do not contract insurance. Statistically significant linear relationship between these two variables has not been identified and hypothesis is rejected.

Insurance companies should improve Customer Relationship Management (CRM) in order to increase awareness and to give additional information to farmers as potential insureds, to innovate portfolio of insurance products and develop supply according to the specific needs of farmers. 


\section{Acknowledgements}

The results presented in this paper are the part of the project "The role of the crop insurance in the financing consequences of realization of natural disasters in Vojvodina: actual state and perspectives", financed by Agriculture Secretariat of Autonomous Province of Vojvodina.

\section{Conflict of interests}

The authors declare no conflict of interest.

\section{References}

1. Baez, M.S. \& Wong, S. (2007). Insurance in emerging markets: sound development; Greenfield for agricultural insurance. Sigma, Zurich, 1/2007.

2. Croatian Bureau of Statistics (2010). Structure on farmers'households, Zagreb. https://www.dzs.hr/default e.htm

3. Čolović, V., Mrvić Petrović, N. (2014). Crop Insurance - Risk and Models of Insurance, Economics of Agriculture, 61(3), 561-573.

4. DDOR (1996). Handbook for practice in insurance and reinsurance [in Serbian: DDOR, (1996), Priručnik za praksu u osiguranju i reosiguranju]. DDOR, Novi Sad.

5. European Commission (EC), (2001). Risk Management Tools for EU Agriculture, with a special focus on insurance - Working Document. European Commission, Agriculture Directorate-General, Brussels.

6. GAO, (2012). Crop Insurance: Savings Would Result from Program Changes and Greater Use of Data Mining, GAO-12-256, Report to the Ranking Member, 741EP 2013 (60) 4 (729-743) Permanent Subcommittee on Investigations, Committee on Homeland Insurance and Governmental Affairs, U.S. Senate, United States Government Accountability Office, Washington, DC.

7. Hirsch, B. \& Nell, M. (2008). The Law \& Economics of Epidemic Livestock Disease Risk Management. In Eger, T., Bigus, J., Ott, C., von Wangenheim, G. (Ed.), Internationalization of the Law and its Economic Analysis, Gabler, Wiesbaden, 239-249.

8. Kaira, A. \& Xing, L. (2013). Partnering for food security in emerging markets. Sigma, Zurich, 1/2013.

9. Mahul, O. \& Stutley, C. J. (2010). Government Support to Agricultural Insurance: Challenges and Opportunities for Developing Countries. World Bank, Washington, DC.

10. Montenegro statistical office (2011). Agricultural Census 2010 - Structure of farmers' households. Key variables - land and livestock fund, Podgorica. http://www.monstat.org/eng/ 
11. National Bank of Serbia (2017). Summary of the number of insurance policies, number of insureds and premiums according to insurance types and tariffs in Serbia in 2015. [in Serbian: Преглед броја осигурања, броја осигураника и премије по врстама и тарифама осигурања за Србију у 2015. години. Народна банка Србије, Београд].

12. Njegomir, V., Pejanović, Lj. \& Keković, Z. (2017). Agricultural Entrepreneurship, Environmental Protection and Insurance, Economics of Agriculture, 64(3), 1035-1049.

13. Njegomir, V., Marović, B., Pejanović, R. \& Kuzmanović, B. (2017). Climate Changes and Insurance of Agriculture, Princip Press, Beograd. [in Serbian: Његомир, В., Маровић, Б., Пејановић, Р. \& Кузмановић, Б. (2017). Климатске промене и осигурање пољопривреде. ].

14. Njegomir, V., Tepavac, R. \& Bikicki, T. (2016). Risk management in agriculture under climate changes. Economics of Agriculture, 63(4), 1403-1417.

15. Patrick, G.F., Peiter, A.J., Knight, T.O., Coble, K.H. \& Baquet, A.E. (2007). Hog producers' risk management attitudes and desire for additional risk management education. Journal of Agricultural and Applied Economics, 39(3), 671-687.

16. Pejanović, R. \& Njegomir, V. (2011). Problems of risk management in the agriculture, Economics of Agriculture, 58(1), 91-103.

17. Raulston, J.M., Richardson, J.W., Outlaw, J.L. \& Knapek, G.M. (2010). Does Crop Insurance Reduce the Need for Cash Reserves in Savings Accounts?. Paper presented at the SAEA Annual Meeting, Orlando, FL.

18. Rejda, G.E. (2005). Principles of Risk Management and Insurance. Upper Saddle River, Pearson Education, Inc, New York.

19. Skakavac, Z., Njegomir, V., Pejanović, Lj. \& Skakavac, A. (2017). Risk Management of Agricultural Floods, Economics of Agriculture, 64(2), 639569.

20. Skees, J., Hazell, P. \& Miranda, M. (1999). New Approaches to Crop Yield Insurance in Developing Countries. EPTD Discussion Paper 55. International Food Policy Research Institute, Washington, DC.

21. State Statistical Office of Republic of Macedonia (2007). Agricultural Census 2007. Book III: Individual farms grouped by total available land area, by region, Skopje. http://www.stat.gov.mk/Default en.aspx

22. Statistical Office of the Republic of Serbia (2003). Census 2002 - Agriculture, Agriculture funds, municipalities' data, Belgrade. http://www.stat.gov.rs/en-US/

23. Statistical Office of the Republic of Serbia (2013). Census of Agriculture 2012 in the Republic of Serbia - Agriculture in the Republic of Serbia, http://pod2. stat.gov.rs/ObjavljenePublikacije/Popis2012/PP-knjiga1.pdf and http://pod2. stat.gov.rs/ObjavljenePublikacije/Popis2012/PP-knjiga2.pdf 
24. Statistical Office of the Republic of Slovenia (2010). Important data on Agricultural Census: land, market gardening, livestock numbers, agricultural machinery. Ljubljana. http://www.stat.si/statweb/en/home

25. World Bank (2008). Framework document for proposed loans, credits, and grants in the amount of US\$1.2 billion equivalent for a global food crisis response program. World Bank Washington, DC.

26. World Bank (2013). World Development Indicators Database. World Bank, New York. https://datacatalog.worldbank.org/dataset/world-developmentindicators

27. Žarković, N., Toscano, B., Mrkšić, D. \& Lisov, M. (2014). Key Features of Crop Insurance in Serbia. Bulgarian Journal of Agricultural Science, 20(1), 23-33. 